Revista Brasileira de Farmacognosia Brazilian Journal of Pharmacognosy 22(4): 818-824, Jul./Aug. 2012

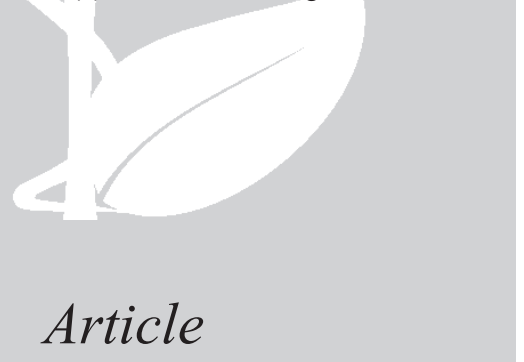

Received 28 Nov 2011

Accepted 24 Jan 2012

Available online 14 Jun 2012

Keywords:

Gracilariaceae

carposporeling development

temperature

salinity

irradiance

ISSN 0102-695X

http://dx.doi.org/10.1590/S0102-

$695 \times 2012005000079$

\section{Effects of temperature, salinity and irradiance on carposporeling development of Hidropuntia caudata (Gracilariales, Rhodophyta)}

\author{
George E. C. de Miranda, ,', Nair S. Yokoya, ${ }^{2}$ Mutue T. Fujii ${ }^{2}$ \\ ${ }^{1}$ Departamento de Sistemática e Ecologia, Universidade Federal da Paraiba, Brazil, \\ ${ }^{2}$ Núcleo de Pesquisa em Ficologia, Instituto de Botânica, Secretaria de Estado do Meio \\ Ambiente, São Paulo, Brazil.
}

\begin{abstract}
The success of seaweed cultivation depends on the scientific control of the tolerance limits and the optimal physiological conditions that affect the spore germination and the early development of algal species. In order to establish cultivation techniques for spores of Hidropuntia caudata (J. Agardh) Gurgel \& Fredericq, the effects of irradiance, salinity, and temperature on the carpospore germination and carposporeling development were evaluated under laboratory conditions. Five photon flux densities (PFD, from 18 to $200 \mu \mathrm{mol}$ photons $\mathrm{m}^{-2} \mathrm{~s}^{-1}$ ), six salinity values (from 7 to $55 \mathrm{psu}$ ), and four temperatures (from $20{ }^{\circ} \mathrm{C}$ to 35 ${ }^{\circ} \mathrm{C}$ ) were investigated. The level of irradiance caused significant differences in the growth, in the following order: $200 \pm 5>100 \pm 5=62.5 \pm 2.5>30 \pm 1.5>18 \pm 1 \mu \mathrm{mol}$ of photons $\mathrm{m}^{-2} \mathrm{~s}^{-1}$, but they did not inhibit the carposporeling development. Maximum growth occurred under $35 \mathrm{psu}$, while at 15 psu the formation of carposporeling erect axis was limited. The optimal temperature for growth was $25{ }^{\circ} \mathrm{C}$, while at $35^{\circ} \mathrm{C}$ the spores died. These results show the importance of previous knowledge on the tolerance limits and optimal conditions for sporeling development of $H$. caudata for the implementation of an aquaculture program.
\end{abstract}

\section{Introduction}

Members of the family Gracilariaceae are the main source of agar throughout the world (Oliveira et al., 2000; Ye et al., 2006). In Brazil, the exploitation of seaweeds for agar production occurs mainly in the northeastern part of country using the following species: Gracilaria birdiae Plastino \& Oliveira, G. domingensis (Kützing) Sonder ex Dickie, Hydropuntia caudata (J. Agardh) Gurgel \& Fredericq, and H. cornea (J. Agardh) M.J. Wynne (Oliveira \& Miranda, 1998; Oliveira et al., 2000). The harvesting of $H$. caudata (previously named Gracilaria caudata J. Agardh) from natural populations became a common practice in northeastern Brazil and expanded rapidly since the 1970s (Oliveira Filho, 1981; Oliveira, 1998; Oliveira \& Miranda, 1998,), but this activity had to be suspended due to the reduction in the natural populations (Miranda, 2008). Critchley (1993) and Oliveira et al. (2000) discuss the fact that these natural populations cannot withstand the growing demand required for the production of phycocolloid.

Hidropuntia caudata is abundant in tropical waters of the western Atlantic Ocean and occurs along the Brazilian coast (Joly et al., 1963; Silva et al., 1987; Plastino \& Oliveira, 1997; Oliveira, 1998; Oliveira \&
Miranda, 1998; Chow et al., 2007). It is found in clear to turbid water in the mid-littoral zone or infra-littoral fringe, commonly buried in sand, and has a cylindric erect branched thallus, which can reach more than 30 $\mathrm{cm}$ high (Plastino \& Oliveira, 1997).

Wikfors \& Ohno (2001), and Ye et al. (2006) advocate that the transition from the exploitation of natural seaweed populations to the establishment of a successful method of commercial cultivation depends on the development of suitable cultivation technologies. In this way, various authors developed methods for cultivating Gracilariaceae by using its spores (Glenn et al. (1996, 1998); Alveal et al. (1997); Avila et al. (2001)). Alveal et al. (1997) and Mantri et al. (2009) define the understanding of spore biology as the most important step, which determines the success of spore cultivation methods.

The aim of this work was to evaluate the effects of temperature, salinity, and irradiance on the carposporeling development of Hydropuntia caudata, defining the tolerance ranges and optimal growth conditions. This information is fundamental to the development of cultivation programs using spores and techniques contributing to the restoration of overexploited natural populations of $H$. caudata in Brazil. 


\section{Materials and Methods}

\section{Culture conditions and liberation of carpospores}

Fertile female gametophytes of Hidropuntia caudata were collected at Itamaracá beach, Pernambuco

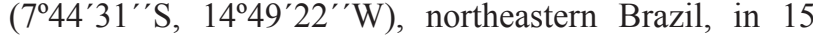
October, 2007, and transported to the Laboratório de Cultura de Algas e Cianobactérias "Marilza CordeiroMarino” at the Instituto de Botânica in São Paulo, Brazil. The specimens were maintained in culture medium composed by sterilized seawater enriched with $25 \%$ of Von Stosch (VSES/4) solution (Edwards, 1970) with a 50\% reduction in the vitamin concentrations, according with Yokoya (2000), at $23 \pm 1{ }^{\circ} \mathrm{C}$ ), with a photon flux density of 60 to $70 \mu \mathrm{mol}$ photons $\mathrm{m}^{-2} \mathrm{~s}^{-1}$, and $30 \mathrm{psu}$ (practical salinity units). To reduce the growth of diatoms, $1 \mathrm{mg} . \mathrm{L}^{-1}$ of germanium dioxide was added to the medium (Lewin, 1966).

The liberation of carpospores was induced under low irradiance $\left(<10 \mu \mathrm{mol}\right.$ of photons $\left.\mathrm{m}^{-2} \mathrm{~s}^{-1}\right)$ as suggested by Orduña-Roja \& Robledo (1999). Thallus segments of approximately $1 \mathrm{~cm}$ in length, with one to three cystocarps, were isolated and transferred to glass slides $(2 \times 2 \mathrm{~cm})$ placed inside Petri dishes with culture medium (VSES/4). After $48 \mathrm{~h}$, the carpospore diameters were measured, and the slides with released carpospores were cultivate in approximately $150 \mathrm{~mL}$ of VSES/4 medium. For all experiments, the culture medium was changed weekly and the photoperiod was 12:12 h (light:dark cycle).

Effects of irradiance, salinity and temperature on carposporeling development

Photon flux density (PFD)

Five treatments were tested in a culture chamber with different photon flux densities: $200 \pm 5$ $\mu \mathrm{mol}$ photons $\mathrm{m}^{-2} \mathrm{~s}^{-1} ; 100 \pm 5 \mu \mathrm{mol}$ photons $\mathrm{m}^{-2} \mathrm{~s}^{-1}$; $62.5 \pm 2.5 \mu \mathrm{mol}$ photons $\mathrm{m}^{-2} \mathrm{~s}^{-1} ; 30 \pm 1.5 \mu \mathrm{mol}$ photons $\mathrm{m}^{-2} \mathrm{~s}^{-1}$, and $18 \pm 1 \mu \mathrm{mol}$ photons $\mathrm{m}^{-2} \mathrm{~s}^{-1}$. Each treatment was tested with four replicates $(n=4)$.

Salinity

Different levels of salinity were obtained by freezing and melting seawater, as described by Yokoya \& Oliveira (1992). The following salinity values were obtained and checked with a refractometer (American Optical): 7, 15, 25, 35, 45, and 55 psu. Each treatment was tested with three replicates $(n=3)$.

Temperature

The experiments were performed in a cultivation chamber at the temperatures of 20, 25, 30, and $35{ }^{\circ} \mathrm{C}\left( \pm 0.5{ }^{\circ} \mathrm{C}\right)$. Each treatment was tested with three replicates $(n=3)$.

In all the tested treatments, the carposporeling growth for each replicate was evaluated weekly by measuring the diameter of the basal disc and the length of the erect axis of twenty plantlets, which are sampled randomly. Growth rate (GR) was calculated according to Brinkhuis (1986), following the formula GR $=(\ln$ final length - In initial length)/(final time - initial time); in this formula, the initial measurement corresponds to the basal disc diameter and the final measurement corresponds to the length of the erect axis.

\section{Statistical analysis}

Normality and homocedasticity of data were tested. Unifactorial analysis of variance ANOVA $(p=0.05)$ was performed when possible and a posterior $i$ Student-Newman Keuls test was used to compare the treatments that were statistically different. When the normality and homogeneity requirements of the variances were not observed, the non-parametric Kruskal-Wallis test was performed according to Zar (1999). SigmaStat was used to perform the statistical calculations. Linear regression was used to verify the correlation between the tested factors and the growth of Hydropuntia caudata (Zar, 1999).

\section{Results}

The germination pattern of Hydropuntia caudata carpospores observed in the present study was similar to that described by Yokoya (1993), Polifrone et al. (2006), Yeong et al. (2008), and Mantri et al. (2009) and corresponds to the Dumontia-type according to Guiry (1990). A very common characteristic observed was the coalescence of basal discs, which gave rise to three or more erect axis. The initial branching of the erect axis occurred both laterally and at the apical part of axis. The germination of the carpospores was also observed in situ, occurring on the cystocarp of the mother plant (Figure 1).

\section{Effect of irradiance on carposporeling development}

The carpospores used in the irradiance experiments had an initial diameter of $23.37 \pm 0.37$ $\mu \mathrm{m}$. None of the photon flux densities tested inhibited carpospore germination or limited the growth of the carposporeling erect axis. The variance analysis and the a posteriori Student-Newman-Keuls test indicated that there were differences among all treatments, except between treatments at $100 \pm 5 \mu \mathrm{mol}$ photons $\mathrm{m}^{-2} \mathrm{~s}^{-1}$ and at 
Effects of temperature, salinity and irradiance on carposporeling development of Hidropuntia caudata (Gracilariales, Rhodophyta) George E. C. de Miranda et al.

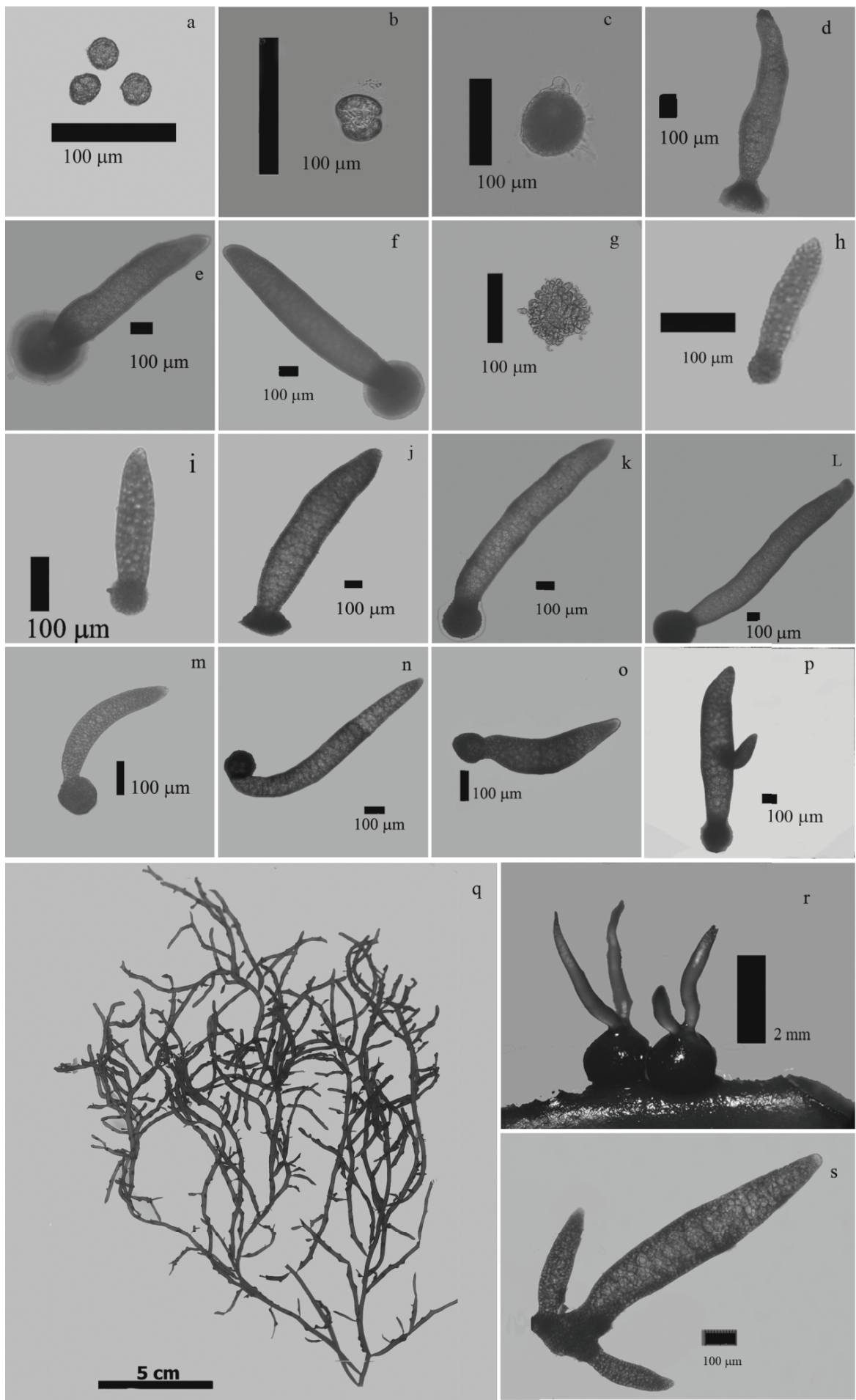

Figure 1. Carpospore germination and development of carposporeling in Hidropuntia caudata. a: carpospores; b: dead carpospores submitted to $07 \mathrm{psu}$ salinity in the first week of the experiment; c, d, e, and f: carposporelings at the end of the salinity experiment after 26 days, at 15, 25, 35, and 45 psu, respectively; g: carposporelings cultivated in a salinity of 55 psu, after seven days; h, i, j, k, and l: carposporelings submitted to different PFD levels after 31 days; $\mathrm{h}: 17$ to $19 \mu \mathrm{mol}$ photons $\mathrm{m}^{-2} \mathrm{~s}^{-1} ; \mathrm{i}: 29$ to $32 \mu \mathrm{mol}$ photons $\mathrm{m}^{-2} \mathrm{~s}^{-1}$; j: 60 to $65 \mu \mathrm{mol}$ photons $\mathrm{m}^{-2} \mathrm{~s}^{-1}$; $\mathrm{k}$ : 95 to $105 \mu \mathrm{mol}$ photons $\mathrm{m}^{-2} \mathrm{~s}^{-1}$; and 1: 195 to $205 \mu \mathrm{mol}$ photons $\mathrm{m}^{-2} \mathrm{~s}^{-1} ; \mathrm{m}, \mathrm{n}$, and o: carposporelings submitted to different temperatures $\left(20,25\right.$, and $30^{\circ} \mathrm{C}$, respectively) after 25 days; p: detail of the lateral branch of a carposporeling cultured in the laboratory after 31 days; q: general view of the thallus of $H$. caudata; $\mathrm{r}$ : in situ germination of the non-released carpospores inside cystocarps, detail of the apical branch of the plantlet; s: fusion of basal discs of different plantlets. 
$62.5 \pm 2.5 \mu \mathrm{mol}$ photons $\mathrm{m}^{-2} \mathrm{~s}^{-1}$. Thus, the comparison of the carposporeling growth among the treatments was the following: $200 \mu \mathrm{mol}$ of photons $\mathrm{m}^{-2} \mathrm{~s}^{-1}>100 \mu \mathrm{mol}$ of photons $\mathrm{m}^{-2} \mathrm{~s}^{-1} \cong 62.5 \mu \mathrm{mol}$ of photons $\mathrm{m}^{-2} \mathrm{~s}^{-1}>30 \mu \mathrm{mol}$ of photons $\mathrm{m}^{-2} \mathrm{~s}^{-1}>18 \mu \mathrm{mol}$ of photons $\mathrm{m}^{-2} \mathrm{~s}^{-1}(>$ ou $<$ $=$ statistically different; $\cong=$ not statistically different $)$. A strong positive correlation was found between the photon flux and the length of the erect axis with an $r=$ 0.98 . Figure 2 shows the values of the growth rates at the end of the experiment.

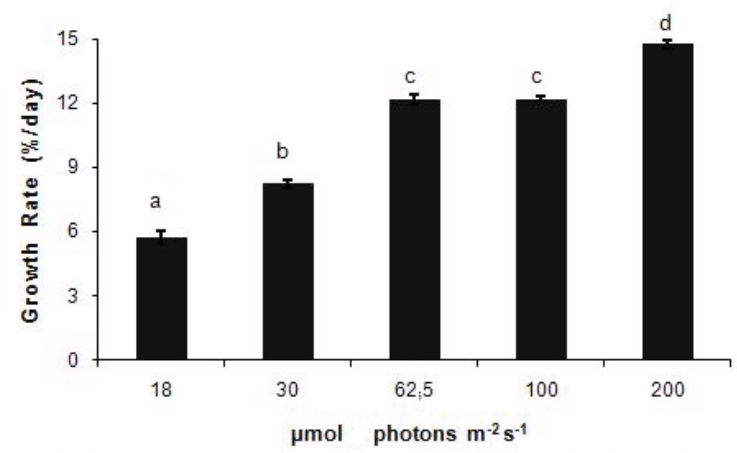

Figure 2. Growth rates of $H$. caudata in the experiments with different irradiances during 31 days $(n=4$; average of twenty measurements for each replicate). Bars represent standard deviations. Different letters indicate significant differences among the treatments according to the Student-Newman Keuls multiple comparison test $(p=0.05)$.

The formation of the basal discs was affected by the different PFD treatments. The results were not statistically different between $200 \pm 5 \mu \mathrm{mol}$ photons $\mathrm{m}^{-2} \mathrm{~s}^{-1}$ and $100 \pm 5 \mu \mathrm{mol}$ photons $\mathrm{m}^{-2} \mathrm{~s}^{-1}$, as well as between $30 \pm 1.5 \mu \mathrm{mol}$ photons $\mathrm{m}^{-2} \mathrm{~s}^{-1}$ and $18 \pm 1 \mu \mathrm{mol}$ photons $\mathrm{m}^{-2} \mathrm{~s}^{-1}$. Thus, the decreasing order of the growth of the basal disc was the following: $200 \mu \mathrm{mol}$ photons $\mathrm{m}^{-2} \mathrm{~s}^{-1} \cong 100 \mu \mathrm{mol}$ photons $\mathrm{m}^{-2} \mathrm{~s}^{-1}>62.5 \mu \mathrm{mol}$ photons $\mathrm{m}^{-2} \mathrm{~s}^{-1}>30 \mu \mathrm{mol}$ photons $\mathrm{m}^{-2} \mathrm{~s}^{-1} \cong 18 \mu \mathrm{mol}$ photons $\mathrm{m}^{-2} \mathrm{~s}^{-1}(>=$ statistically different; $\cong=$ not statistically different).

\section{Effect of salinity on carposporeling development}

The carpospores used to evaluate the effect of salinity had a diameter of $23.49 \pm 0.56 \mu \mathrm{m}$ at the beginning of the experiment. Minimum and maximum tolerance limits for the germination were above 07 psu and below 55 psu, respectively. These values were lethal, prevented or inhibited the formation of basal discs and erect axes. The formation of the basal disc was influenced by salinity variations; however, there were no statistical differences between 25 and 45 psu. The following decreasing order in diameter of the disc was observed: $25 \mathrm{psu} \cong 35 \mathrm{psu} \cong 45 \mathrm{psu}>15 \mathrm{psu}>55$ psu. The salinity level of $07 \mathrm{psu}$ was lethal to the spore germination.

Maximum growth was observed at the salinity of $35 \mathrm{psu}$. Salinity of $15 \mathrm{psu}$ inhibited the formation of erect axis and the carposporeling developed only a basal disc. Data on the growth of the erect axis indicated the decreasing order of: $35 \mathrm{psu}>45 \mathrm{psu}>25 \mathrm{psu}>15 \mathrm{psu}$, with statistical differences. Figure 3 shows the daily growth rate of the carposporelings at the tested salinity levels. There was no linear correlation between the increasing salinity levels tested and the carposporeling growth $(r$ Pearson $=0.20)$.

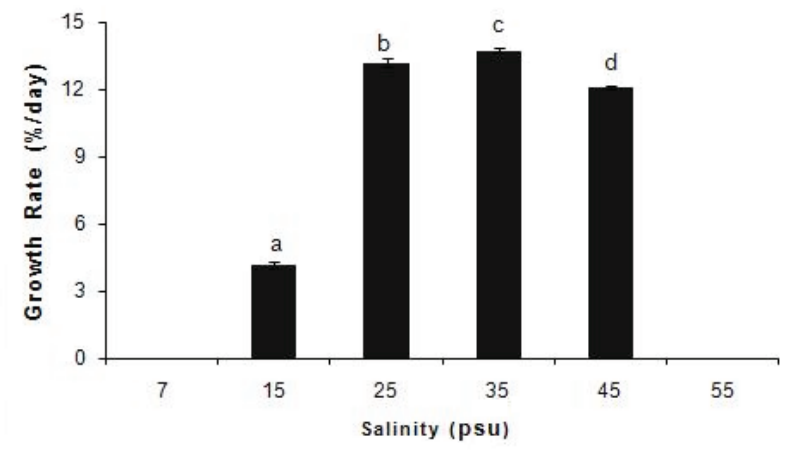

Figure 3. Growth rates of $H$. caudata in the experiments with different salinities during 26 days $(n=3$; average of twenty measurements for each replicate). Bars represent the standard deviations. Different letters indicate significant differences among the treatments according to the Student-Newman Keuls multiple comparison test $(p=0.05)$ or * Kruskal-Wallis non-parametric test.

\section{Effect of temperature on carposporeling development}

The carpospores used in the temperature experiment had an average diameter of $23.39 \pm 0.30 \mu \mathrm{m}$. A temperature of $35^{\circ} \mathrm{C}$ was lethal to spore germination. The highest growth was observed at $25^{\circ} \mathrm{C}$, followed by 30 and $20{ }^{\circ} \mathrm{C}$, respectively (Figure 1). The statistical analyses showed differences between the growth rates at $25{ }^{\circ} \mathrm{C}$ when compared to the other temperatures tested. There were no statistical differences in the carposporeling growth rates cultured at $20^{\circ} \mathrm{C}$ compared to those cultured at $30{ }^{\circ} \mathrm{C}$ (Figure 4 ).

There was no linear correlation $(r$ Pearson $=$ 0.09 ) between the increase of temperature and growth. The formation of the basal disc was not statistically different based on the temperatures tested. Differences were significant only after the erect axis started to grow.

\section{Discussion}

In the Dumontia-type germination pattern 
observed in Hidropuntia caudata, the fusion of the basal discs from various sporelings was observed. This could explain the genetic mosaics that Kain \& Destombe (1995) called chimeras, where the fusion of the discs can create complex genetic systems with distinct genotypes in a single thallus. Plastino et al. (1999) and Polifrone et al. (2006) verified the formation of a sexual mosaic caused by the germination of tetraspores in situ and the development of gametophytes in the same thallus of the tetrasporophytes. Another factor that could explain the presence of the so-called chimeras is the germination of the carpospores inside of the cystocarp, giving rise to a system where the female gametophyte (haploid) acts as a support for the tetrasporophyte (diploid) (Figure 1).

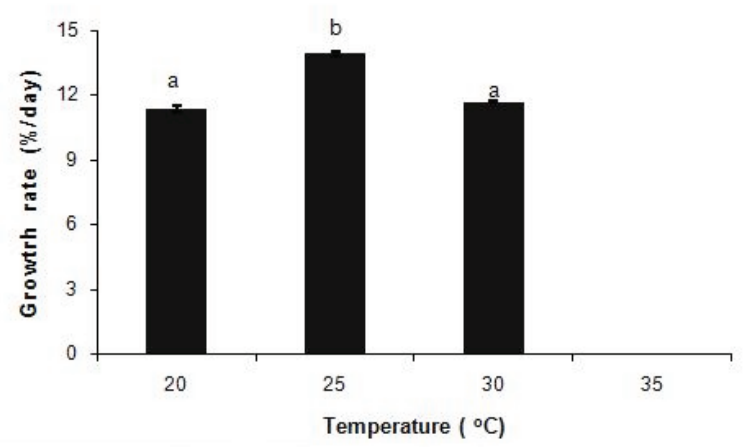

Figure 4. Growth rates of $H$. caudata in the experiments with different temperatures during 25 days ( $n=3$; average of twenty measurements for each replicate). Bars represent standard deviations. Different letters indicate significant differences among the treatmnets according to the Student-Newman Keuls multiple comparison test $(p=0.05)$ or $*$ Kruskal-Wallis non-parametric test.

The effect of the irradiance on spore germination and early development of the sporeling indicated statistical differences between almost every treatment; however, the range of photon flux densities tested in the present study did not limit the development of the alga at any level tested. A high correlation $(\mathrm{r}=0.98)$ between the carposporeling growth of Hidropuntia caudata and the increase of PFD suggests that the saturation irradiance levels are higher than 200 $\mu \mathrm{mol}$ photons $\mathrm{m}^{-2} \mathrm{~s}^{-1}$. Ye et al. (2006) showed negative effects on diameter and survival rate of tetraspores of Gracilariopsis lemaneiformis (Bory de SaintVincent) Dawson, Acleto \& Foldvik (as Gracilaria lemaneiformis) under PFD exceeding $480 \mu \mathrm{mol}$ photons $\mathrm{m}^{-2} \mathrm{~s}^{-1}$. The results for the low values of PFD show that $H$. caudata can survive in low light environments, a fact cited by Plastino \& Oliveira (1997), who reported that this species was common in turbid waters and can also be found growing partially buried in the sand.

For incorporation of the results obtained in the present study into techniques for aquacultural production from carpospores, it is suggested that the PFD of the system be set at approximately $10 \mu \mathrm{mol}$ photons $\mathrm{m}^{-2} \mathrm{~s}^{-1}$ during the seedling phase and at $100 \mu \mathrm{mol}$ photons $\mathrm{m}^{-2} \mathrm{~s}^{-1}$ during the first week of development, since a value above this showed no statistical difference in the formation of the basal disc. Starting at the second week of development, a PFD value of $200 \mu \mathrm{mol}$ photons $\mathrm{m}^{-2} \mathrm{~s}^{-1}$ or higher is desirable to promote a significant increase in the growth of the erect axis.

The tolerance limit to salinity variation was wide, ranging from 15 to $45 \mathrm{psu}$, while optimum growth occurred at $35 \mathrm{psu}$. These values are similar to those described by Bird \& McLachlan (1986), who demonstrated the euryhaline character of Gracilaria. The salinity values obtained in laboratory experiment also coincide with the values found in the region where the $H$. caudata population was collected, with a salinity level of approximately $36 \mathrm{psu}$, but that can decrease to 20 psu during the rainy season (Silva et al., 1987). The tolerance limits for carposporeling growth of $H$. caudata presented discrete differences when compared to the results obtained by Yokoya \& Oliveira (1993) for a distinct population of the same species collected from southeastern Brazil, especially for the lower limit (20 psu) and for the optimal growth level (25 psu). One hypothesis is that the populations are locally adapted and have distinct tolerance limits to salinity levels.

The results obtained in relation to the temperature diverge from those found by Yokoya \& Oliveira (1993) and Macchiavello et al. (1998) for the same species. According to these authors, the optimal growth temperature was $30^{\circ} \mathrm{C}$. The results obtained in the present study showed optimal growth at $25^{\circ} \mathrm{C}$, while at 20 and $30^{\circ} \mathrm{C}$ the growth values were sub-optimal and there were no statistical differences in the growth rates. The highest temperature employed in the present work, which was lethal to $H$. caudata, was approximately 35 ${ }^{\circ} \mathrm{C}$, which is similar to the limit of $32.8{ }^{\circ} \mathrm{C}$ indicated by Macchiavello et al. (1998). A lower limit was not determined in the present work, but it is reported to be approximately 14 and $13.8{ }^{\circ} \mathrm{C}$ by Yokoya \& Oliveira (1993) and Macchiavello et al. (1998), respectively. For an application point of view, the optimal temperature of $25^{\circ} \mathrm{C}$ observed in this study for the carposporeling development should not be used indiscriminately in the development of general cultivation techniques of $H$. caudata, since there are locally acclimated populations that have different optimal values.

It is important to observe that the basal disc growth was not statistically different at the temperatures of 20 and $30^{\circ} \mathrm{C}$. These differences were significant only after the development of erect axis.

These results show the importance of previous knowledge about the tolerance limits and optimal 
conditions for sporeling development of Hidropuntia caudata before implementing an aquacultural program. The results also suggest that generalization of the values obtained from studies of populations from different regions could reduce productivity because of the development of carposporelings under sub-optimal conditions.

\section{Acknowledgements}

The authors are grateful to $\mathrm{CNPq}$, Brazil, for financial support provided by Edital 10/2006. GECM thanks CAPES for a PhD fellowship; MTF and NSY thank $\mathrm{CNPq}$ for the research fellowships.

\section{References}

Alveal K, Romo H, Werlinger C, Oliveira EC 1997. Mass cultivation of the agar producing alga Gracilaria chilensis (Rhodophyta) from spores. Aquaculture 148: 77-83.

Bird CJ, McLachlan J 1986. The effect of salinity on distribuition of species of Gracilaria Grev. (Rhodophyta, Gigartinales): an experimental assessment. Bot Mar 29: 231-238.

Brinkhuis BH 1986. Growth patterns and rates. In Litler M, Litler D (ed.) Handbook of Phycological Method Ecological Field Methods: Macroalgae. Cambridge: Cambridge Press, p. 461-477.

Chow F, Capociama FV, Faria R, Oliveira MC 2007. Characterization of nitrate reductase activity in vitro in Gracilaria caudata J. Agardh (Rhodophyta, Gracilariales). Rev Bras Bot 30: 123-129.

Critchley AT 1993. Gracilaria (Rhodophyta, Gracilariales): an economically important agarophyte. In Ohno M, Critchley AT (eds.) Seaweed cultivation and marine ranching. Yokosuka: Kanagawa International Fisheries Training Center and JICA, p. 89-112.

Edwards P 1970. Illustrated guide to the seaweeds and sea grasses in the vicinity of Porto Aransas, Texas. Contr Mar Sc Austin 15 (sup.): 1-228.

Glenn EP, Moore D, Fitzsimmons K, Azevedo C 1996. Spore culture of the edible red seaweed, Gracilaria parvispora (Rhodophyta). Aquaculture 142: 59-74.

Glenn EP, Moore D, Brown JJ, Tanner R, Fitzsimmons K, Akutigawa M, Napolean S 1998. A sustainable culture system for Gracilaria parvispora (Rhodophyta) using sporelings, reef growgout and floating cages in Hawaii. Aquaculture 165: 221-232.

Guiry MD 1990. Sporangia and spores. In Cole KM, Sheath RG (ed.) Biology of the Red Algae. Cambridge: Cambridge University Press, p. 347-376.

Joly AB, Cordeiro M, Mendoza ML, Yamaguishi N, Ugadim Y 1963. Additions to the marine flora of Brazil. III. Bol Fac Filos Ciên L Univ S Paulo, Sér Bot 20: 7-21.
Kain J, Destombe C 1995. A review of the life history, reproduction and phenology of Gracilaria. J Appl Phycol 7: 269-281.

Lewin J 1966. Silicon metabolism in diatoms. V. Germanium dioxide, a specific inhibitor of diatom growth. Phycologia 6: 1-12.

Macchiavello J, Paula EJ, Oliveira EC 1998. Growth rate responses of five commercial strains of Gracilaria (Rhodophyta, Gracilariales) to temperature and light. $J$ World Aquacult Soc 29: 259-265.

Mantri VA, Thakur MC, Reddy CRK, Jha B 2009. The carpospore culture of industrially important red alga Gracilaria dura (Gracilariales, Rhodophyta). Aquaculture 297: 85-90.

Miranda GEC 2008. Cultivo de macroalgas no Brasil - o longo caminho para a sustentabilidade. In Loiola MIB, Baseia I, Lichston JE (eds.) In Atualidades, Desafios e Perspectivas da botânica no Brasil, Anais $59^{\circ}$ Cong. Brasileiro de Botânica. Natal: Ed. Imagem, p. 506-508.

Oliveira Filho EC 1981. A exploração de algas marinhas no Brasil: situação atual e perspectivas futuras. Phycol Latino Amer 1: 5-17.

Oliveira EC 1998. The seaweed resources of Brazil. In Critchley A, Ohno M (eds.) Seaweeds of the World. Yokosuka: JICA, p. 366-371.

Oliveira EC, Miranda GEC 1998. Aspectos sociais e econômicos da explotação de algas marinhas no Brasil. Anais IV Congr Latino-amer, II Reunião Ibero-amer e VII Reunião Brasil Ficol 2: 149-156.

Oliveira EC, Alveal K, Anderson R 2000. Mariculture of the agar-producing Gracilarioid red algae. Rev Fish Sci 8: 345-378.

Orduña-Rojas J, Robledo D 1999. Effect of irradiance and temperature on the release and growth of carpospores from Gracilaria cornea J. Agardh (Gracilariales, Rhodophyta). Bot Mar 42: 315-319.

Plastino EM, Guimarães M, Matioli SR, Oliveira EC 1999. Codominante inheritance of polymorphic color variants of Gracilaria domingensis (Gracilariales, Rhodophyta). Genet Mol Biol 22: 105-108.

Plastino EM, Oliveira EC 1997. Gracilaria caudata J. Agardh (Gracilariales, Rhodophyta) - restoring an old name for a common western Atlantic alga. Phycologia 36: 225-232.

Polifrone M, Masi FD, Gargiulo GM 2006. Alternative pathways in the life history of Gracilaria gracilis (Gracilariales, Rhodophyta) from north-eastern Sicily (Italy). Aquaculture 261: 1003-1013.

Silva RL, Pereira, SMB, Oliveira Filho EC, Eston VR 1987. Structure of a bed of Gracilaria spp. (Rhodophyta) in Northeastern Brazil. Bot Mar 30: 517-523.

Wikfors GH, Ohno M 2001. Impact of algal research in aquaculture. J Phycol 37: 968-974.

Ye N, Wang H, Wang G. 2006. Formation and early development 
of tetraspores of Gracilaria lemaneiformis (Gracilaria, Gracilariaceae) under laboratory conditions. Aquaculture 254: 219-226.

Yeong HY, Khalid N, Phang SW 2008. Protoplast isolation and regeneration from Gracilaria changii (Gracilariales, Rhodophyta). J Appl Phycol 20: 641-651.

Yokoya NS 2000. Apical callus formation and plant regeneration controlled by plant growth regulators on axenic culture of the red alga Gracilariopsis tenuifrons (Gracilariales, Rhodophyta). Phycol Res 48: 133-142.

Yokoya NS, Oliveira EC 1992. Effects of salinity on the growth rate, morphology and water content of some Brazilian red alga of economic importance. Cienc Mar 18: 49-64.
Yokoya NS, Oliveira EC 1993. Effects of temperature and salinity on spore germination and sporeling development in South American agarophytes (Rhodophyta). Jpn J Phycol 41: 283-293.

Zar JH 1999. Biostatistical Analysis. New Jersey: Prentice Hall.

\section{*Correspondence}

George E. C. de Miranda

Universidade Federal da Paraíba

CCEN/DSE, 58059-900 João Pessoa-PB, Brazil

mirandag@dse.ufpb.br

Tel. +5583 32167464 